\title{
Brugen af vejlederbrev til universitetsstuderende - en diskussion af dets betydning i vejledningsprocessen
}

\author{
Sussie Laustsen, adjunkt, ph.d., Institut for Klinisk Medicin og Afdeling \\ for Sygeplejevidenskab, Institut for Folkesundhed, Health, Aarhus \\ Universitet.
}

Gitte Wichmann-Hansen, lektor, ph.d., Center for Undervisningsudvikling og Digitale Medier, Arts, Aarhus Universitet.

Hanne Aagaard, adjunkt, ph.d., Afdeling for Sygeplejevidenskab, Institut for Folkesundhed, Health, Aarhus Universitet.

Golnosh Bahrami, adjunkt, ph.d., Institut for Odontologi, Health, Aarhus Universitet.

Pia Dreyer, adjunkt, ph.d. Afdeling for Sygeplejevidenskab, Institut for Folkesundhed, Health, Aarhus Universitet.

\section{Reviewet artikel}

\begin{abstract}
Siden 2008 har deltagere på Aarhus Universitets (AU) vejledningskurser udarbejdet individuelle vejlederbreve, som de kan anvende i vejledningsprocessen. I artiklen præsenteres en kvantitativ undersøgelse af hvor mange, der anvender vejlederbrevet. Endvidere diskuteres vejlederbrevets potentiale til at fremme relationen $i$ vejledningsprocessen, herunder om vejlederbrevet kan tydeliggøre sammenhænge mellem læringsmål, vurderingskriterier og studerendes læringsaktiviteter.
\end{abstract}

\section{Introduktion}

$\mathrm{AU}$ har igennem flere år satset på at kvalificere universitetsansattes pædagogiske kompetencer, herunder vejlederkompetencer. Der er gennemført kurser for VIPansatte om vejledning af universitetsstuderende fra BA til ph.d.-niveau. Siden 2008 har det været fast praksis, at deltagere på vejledningskurser udformer et vejlederbrev, som de får feedback på og drøfter i fællesskab med de øvrige deltagere. Fra 2010 er der på adjunktpædagogiske kurser indført et valgfrit vejledningsmodul (1 ECTS point), hvor udformning af vejlederbrev er obligatorisk. 
I vejlederbrevet skriver vejlederen, hvad han/hun tilbyder og forventer af den studerende. Vejlederbrevets funktion er at eksplicitere forventninger og praksisser af både institutionel og individuel art. Litteraturen anbefaler, at vejlederbreve anvendes i indledende fase af et vejledningsforløb som et redskab til forventningsstyring mellem den studerende og vejlederen (Rienecker et al. 2005). AU har valgt at følge denne anbefaling. Man har bevidst satset på at bevidstgøre vejledere om deres begrundede valg i egen vejledningspraksis ud fra ønsket om at forskningsbasere vejledningspraksis, at fremme studerendes læring, kvaliteten af specialer og afhandlinger, samt at forbedre studiemiljøet. Denne artikel baserer sig på en undersøgelse om brugen af vejlederbreve på $\mathrm{AU}$.

\section{Baggrund}

Vejlederbrev er en dansk terminologi primært udviklet af Rienecker og Stray Jørgensen (2005). I litteraturen refereres der ofte til contracts (Hockey 1996), mens andre taler om et memorandum of understanding eller blot a written understanding (Oxford Learning Institute: http://www.learning.ox.ac.uk/supervision/stages/expectations/). Andre forfattere taler om, at der udformes spørgsmål eller udsagn, som hhv. den studerede og vejlederen svarer på eller forholder sig til - fx ved brug af en såkaldt expectation scale (Moses, 1985).

Der er flere begrundelser for at udforme og anvende vejlederbreve. For det første kan vejlederbrevet ses som en mulig vej mod alignment, hvis man anlægger en konstruktivistisk vinkel herpå (Biggs \& Tang, 2007). Alignment har rødder i en konstruktivistisk grundantagelse om, at viden ikke overføres men skabes gennem den studerendes egne læringsaktiviteter og -arbejde. Derfor lægges der i denne tradition vægt på, at der i undervisningsplanlægning er sammenhæng mellem læringsmål, undervisningsaktiviteter og vurderingskriterier. Vejlederbrevet muliggør, allerede inden vejledningen påbegyndes, at trække alignment ind i vejledningsforløbet, idet væsentlige elementer i vejlederbrevet kan være at beskrive, hvordan vejleder vil hjælpe den studerende med at opnå sammenhæng mellem læringsmål og vurderingskriterier. Ydermere kan vejlederbrevet bruges til at eksplicitere forventninger til den studerendes læringsaktiviteter samt tydeliggøre ønsker om, at den studerende har en så aktiv og ansvarlig position i vejledningsrelationen som muligt.

For det andet er det fra uddannelsesforskningen kendt, at etablering og vedligeholdelse af relationer i vejledning kan vanskeliggøres af, at parterne har forskellige forventninger (Green \& Powell, 2005; Hockey, 1996; Kiley, 2003; Wright, 2003). Flere studier fremhæver, at vejledningsprocessen kan mislykkes, hvis den studerende har andre forventninger til vejledning end det, vejlederen tilbyder (Harboe, 2000; Holdaway, 1995). I forskningen om vejledning fremhæves, at der ofte er forskellige for- 
ventninger mellem studerende og vejleder. Studerende efterspørger proceskompetencer som fx tilgængelighed, venlighed, engagement, åbenhed, grundighed og struktur. Vejlederne lægger mere vægt på egne faglige kompetencer såsom viden, indsigt, håndværk, netværk og hjælp til finansiering (Woolhouse, 2002; Taylor \& Beasley, 2005). For at mindske denne uoverensstemmelse kan vejlederbrevet være midlet til målet, idet vejlederbrevet både tilbyder afstemning af forventninger og kan give relationen til den studerende legal opmærksomhed - en opmærksomhed der kan fremme studerendes aktive og ansvarlige arbejde med opgaven/projektet (Hockey, 1996; Kiley \& Mullins, 2008). I et review finder Wichmann-Hansen et al. 2007, at forventningsafstemning er essentiel for etablering og vedligeholdelse af vejledningsrelationen, idet uddannelsesforskning peger på, at vejledningsrelationen er afgørende for en vellykket vejledningsproces. Det fremhæves i reviewet, at forventningsafstemning mellem parterne er en forudsætning for at etablere og vedligeholde gode relationer i vejledningsforløbet samt for at skabe gunstige studiebetingelser for den studerende.

Tanken med vejlederbrevet er, at vejlederen og den studerende i fællesskab drøfter den kommende vejledningsproces ( $\mathrm{fx}$ mødeomfang, samarbejdsformer, deadlines, kontaktformer) og ikke mindst produktet (indhold, niveau, ambitioner, tekstfeedback, læringsmål og vurderingskriterier). Brevet skal ikke udleveres eller læses som et fastlåst og eviggyldigt tilbud, der fortæller den studerende: "Det her er, hvad du kan få" - Take it or leave it!" Brevet er et udspil; et oplæg til, at den studerende og vejlederen i fællesskab forhandler sig frem til en konsensus (Rienecker et al., 2005). Eksempelvis kan ambitioner og karakterniveau være konfliktfyldte emner, som nemt bliver tabuer i vejledningen, fordi de to parter har forskellige holdninger og forventninger til produktets kvalitet (Handal \& Lauvås, 2006). Vejlederbreve kan ses som en invitation til at drøfte emner - som et redskab til forhandling om noget, det kan være svært at få ud i det åbne.

Et vejlederbrev kan se forskelligt ud og kan anvendes på forskellig vis. Det kan udleveres inden første vejledning, ved første vejledning, lægges på nettet eller bruges som et baggrundsdokument for vejleder til vejledningsprocessen - dvs. at vejleder har brevet i tankerne under vejledning (Rienecker et al., 2005). AU har igennem en årrække satset på via universitetspædagogiske kurser at fremme brugen af vejlederbrevet (jf. Rienecker et al., 2005). Det er dog uklart, i hvilket omfang og hvordan vejlederbrevene anvendes. Endvidere savnes en diskussion af, om vejlederbrevet kan fremme alignment mellem læringsmål, vejledningsaktiviteter, vurderingskriterier og den studerendes læringsaktiviteter. Formålet med dette studie var at undersøge, $i$ hvilket omfang vejlederbrevet anvendes af vejledere, der har gennemgået kursus i 
brug af vejlederbrev på AU. Studiet blev drevet af interessen for at undersøge, om der er forskel på, hvor udbredt vejlederbreve er afhængigt af vejledernes fakultetsvise tilknytning. Studiet blev udformet, så det også i en vis grad kunne besvare, hvordan vejlederbrevene bruges, $\mathrm{fx}$. om de udleveres på skrift direkte til de studerende eller lægges på nettet, og til hvem brevene udleveres.

Studiet er primært designet til at give kvantitative svar på hoor mange og med hoilken fordeling. Resultaterne har givet anledning til en bredere diskussion af vejlederbrevenes formål og berettigelse. I artiklen diskuterer vi derfor resultaterne med den litteratur, som vejlederbreve skriver sig ind i, og vi rejser spørgsmålet, om vejlederbreve potentielt kan fremme studerendes forståelse af krav, egen rolle samt indflydelse på læring i vejledningsprocessen.

\section{Metode og materiale}

I et tværsnitsdesign blev der udsendt et elektronisk spørgeskema i perioden 20. april til 3. maj 2011. Spørgeskemaet bestod af tre spørgsmål: Tilknytning til fakultetsstruktur; hvilke studerende vejlederbrevet anvendes til; hvordan vejlederbrevet anvendes, herunder om man har det i tankerne, når man drøfter kommende vejledning med studerende, om det udleveres eller er tilgængelig på internettet. Endelig efterspørges en kort begrundelse, såfremt vejlederbrevet ikke anvendes.

Spørgeskemaet blev mailet til adjunkter, lektorer og professorer fra alle fire hovedområder Arts, Business and Social Sciences, Health og Science and Technology på AU, der havde deltaget i vejledningskurser i perioden 2008 til forår 2011. Deltagerne på vejledningskurser blev identificeret med e-mails via underviserne og kursussekretær. Besvarelse forgik anonymt. Der blev per mail udsendt én påmindelse om besvarelse. De indkomne data er primært analyseret med deskriptiv statistik. Efterfølgende diskuteres vejlederbrevets anvendelse i relation til vejledningspraksis, den studerendes forståelse af krav, egen rolle samt indflydelse på læring i vejlederprocessen.

\section{Resultater}

Spørgeskemaer blev mailet til 215 ansatte svarende til ca. 10\% af de VIP-ansatte på AU. 15 svarede, at de ikke havde deltaget i kurset, enten pga. sygdom eller fordi, de fejlagtigt stod på deltagerlisten. 128 af de resterende 200 responderede, dvs. svarprocenten var på $64 \%$.

Fordelingen af respondenterne var $9(7,0 \%)$ fra Arts, 51 (39,8\%) fra Business and Social Sciences, $32(25,0 \%)$ fra Health og $36(28,1 \%)$ fra Science and Technology.

Vi fandt, at 62 af de 128 (48,5\%; 95\% confidens interval (CI) 39,5-57,4\%) anvender vejlederbrevet. Fordelingen af de, der anvender vejlederbreve, var 6 (9,7\%) fra Arts, 
27 (43,5\%) fra Business and Social Sciences, 12 (19,4\%) fra Health og 17 (27,4\%) fra Science and Technology. Af de 66 respondenter, der ikke anvender vejlederbrev, svarede $15(22,7 \%)$, at de overvejer at benytte vejlederbrevet i fremtiden. 7 af de 66 $(10,6 \%)$ svarede, at de ikke havde fået nye studerende, siden de havde været på vejlederkursus og derfor ikke anvendte vejlederbrevet. I figur 1 vises den procentvise fordeling af de, der anvender, og de der ikke anvender vejlederbrev på de fire hovedområder på universitetet.

Figur 1. Prævalens af undervisere på Aarhus Universitets fire hovedområder, der i 2011 anvender deres vejlederbrev.

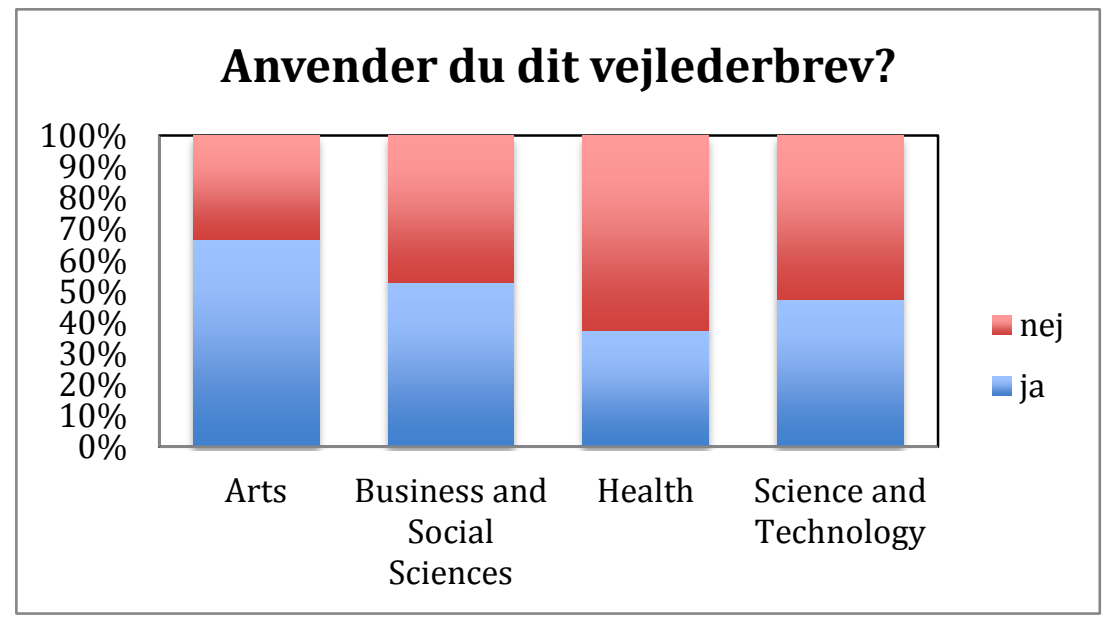

Af de 128 respondenter har 38 (29,7\%; 95\% CI; 21,8 - 37,6) vejlederbrevet i tankerne under vejledning, mens 35 (27,3\%; 95\% CI 19,6 - 35,1) udleverer vejlederbrevet til studerende, og $2(1,6 \%)$ har lagt deres vejlederbrev på internettet. I tabel 1 er vist, hvordan vejlederne indenfor de fire hovedområder anvender vejlederbrevet.

Tabel 1. Prævalens af undervisere på Aarhus Universitet, der i 2011 anvender deres vejlederbrev på tankeplan og udleverer vejlederbrevet.

\begin{tabular}{lcccc}
\hline & \multicolumn{2}{c}{ I tankerne } & \multicolumn{2}{c}{ Udleverer } \\
\cline { 2 - 5 } & Ja & Nej & Ja & Nej \\
& $n(\%)$ & $n(\%)$ & $n(\%)$ & $n(\%)$ \\
\hline Total $\mathrm{n}=128$ & $38(29,7)$ & $90(70,3)$ & $35(27,3)$ & $93(72,7)$ \\
Art $\mathrm{n}=9$ & $2(5,3)$ & $7(7,8)$ & $6(17,1)$ & $3(3,2)$ \\
Business and Social Sciences $\mathrm{n}=51$ & $19(50,0)$ & $32(35,6)$ & $15(42,9)$ & $36(38,7)$ \\
Health $\mathrm{n}=32$ & $9(23,6)$ & $23(25,6)$ & $5(14,3)$ & $27(29,0)$ \\
Science and Technology $\mathrm{n}=36$ & $8(21,1)$ & $28(31,1)$ & $9(25,7)$ & $27(29,0)$ \\
\hline
\end{tabular}


For alle fire hovedområder gælder, at vejlederbrevene anvendes både til ph.d.- og specialestuderende (figur 2). Elleve af de 62 (17,7\%) anvendte vejlederbrevet til begge typer studerende. Som det ses af Figur 2 anvendes vejlederbreve oftest på specialeniveau $\mathrm{p}=0,026$.

Figur 2. Prævalens af undervisere på Aarhus Universitets hovedområder der $i 2011$ anvender deres vejlederbrev til ph.d. - og specialestuderende.

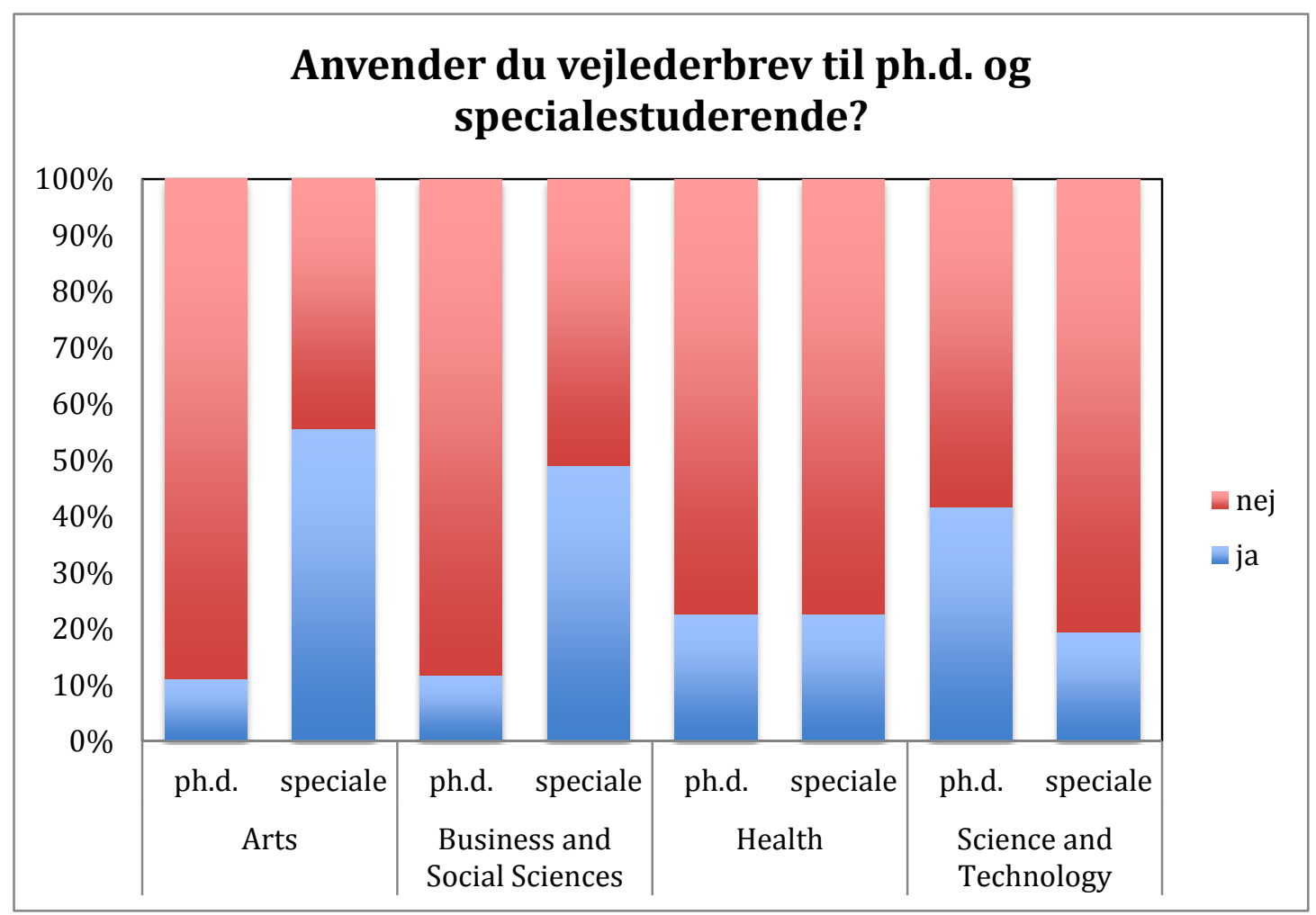

\section{Diskussion}

Undersøgelsen viser, at mindre end en tredjedel anvender vejlederbrevet aktivt ved at udlevere det til studerende. Derimod har ca. $30 \%$ af vejlederne haft overvejelser om vejlederbrevet dog uden at bruge det aktivt. Det er forventeligt med en vis modstand hos vejlederne mod at anvende et nyt redskab, der bryder med traditionel vejledningspraksis. Det er samtidig værd at bemærke, at blandt de, der ikke anvender vejlederbreve, angiver godt en tiendedel, at de overvejer at benytte vejlederbrevet $\mathrm{i}$ fremtiden. Den hyppigste begrundelse for ikke at anvende vejlederbrevet var, at de adspurgte ikke havde fået nye studerende siden vejlederkurset. Denne undersøgelse er foretaget relativt kort tid efter afholdelsen af nogle af kurserne, hvilket kan forklare en begrænset implementering og brug af vejlederbrevet, hvor nogle vejledere ikke har nået at få nye studerende. 
En ting er, hvor mange der bruger vejlederbreve, noget andet er, med hvilken kvalitet og effekt de bruges. Undersøgelsen var ikke designet til at give fyldestgørende svar på sidstnævnte spørgsmål. Alligevel finder vi det relevant at tage hul på diskussionen, da den savnes i litteraturen. Spørgsmålet er, om anvendelse af vejlederbrevet er nok til at skabe sammenhænge mellem læringsmål, vejledningsaktiviteter og vurderingskriterier samt til at påvirke den studerendes læringsaktiviteter i positiv retning? Svaret vil i en konstruktivistisk tænkning være, at vejlederbrevet alene ikke er nok til at skabe alignment. Alignment kræver, at vejleder i enhver kontakt - direkte eller fx i tekstfeedback, skaber rammerne for, at den studerende aktivt arbejder med stoffet i en retning, så der skabes sammenhænge mellem læringsmål og vurderingskriterier. Det teoretiske argument for at vejlederbrevet kan fremme alignment er, at processen med at formulere et vejlederbrev har en bevidstgørende effekt for vejlederen. Uanset hvordan vejlederbrevet efterfølgende anvendes, kan udarbejdelsen af brevet være en bevidstgørelse af vejlederen om at skabe sammenhænge og fremme studieaktiviteter for den studerende i vejledningsprocessen. Argumentet for at skriftliggøre forventninger og praksis er netop ikke kun at eksplicitere og skabe gennemsigtighed for de studerende. Det er lige så væsentligt, at vejlederen bliver bevidst om egen praksis, og at skriveprocessen har en forpligtende form samt en klargørende effekt for skriveren (Dysthe et al., 2001).

Der er en lille tendens til at de tørre fag (Arts og Business and Social Sciences) bruger vejlederbrevet oftere end de våde fag (Health og Science and Technology). En mulig forklaring herpå kan være, at den pædagogiske litteratur har rod i humaniora, hvorfor vejledning oftest diskuteres og undersøges i den humanistiske tradition. Samtidig ligger det ikke fjernt fra den humanistiske tænkning at beskæftige sig med relationer mellem mennesker og reflektere over relationer og læring. Det er veldokumenteret $\mathrm{i}$ uddannelsesforskningen, at læring og vejledning i de våde fag ofte er præget af en traditionel mesterlæretænkning, hvor vejleder og studerende arbejder tæt sammen dagligt fx i et laboratorium, indgår i veletablerede forskningsgrupper, og indgår som parter i et større praksisfælleskab præget af peer- og team-supervision (Seagram et al., 1998; Cullen et al., 1994; Golde \& Dore, 2001; Smeby, 2000). Det kan bevirke, at behovet for at tale om relationer opleves som mindre væsentligt, og at udlevering af vejlederbreve synes overflødigt. I de tørre fag vil vejledningen derimod typisk foregå mellem få personer - ofte i en dyadisk vejlederrelation mellem den studerende og vejlederen. Her er der tale om individuelle opgaver eller forskningsprojekter, hvor der stilles høje krav til den studerendes selvstændighed i arbejdsprocessen, og hvor peer-supervision derfor ikke er oplagt i forløbet (Seagram et al., 1998; Cullen et al., 1994; Golde \& Dore, 2001; Smeby, 2000). Idet vejleder og studerende ikke har en tæt daglig relation, fordrer den dyadiske vejlederform, at der skal skabes tydeligere 
sammenhænge fx med udgangspunkt i vejlederbrevet. Vejlederbrevet kan her blive en legal indgang til skriftligt og mundtligt at italesætte sammenhænge mellem vurderingskriterier og læringsmål samt tydeliggøre, at studerendes læringsaktivitet fremmer udgangspunkt for læring (Biggs \& Tang, 2007).

Den seneste undersøgelse blandt ph.d.-studerende i Danmark viser, at tørre fag har det største frafald blandt ph.d.-studerende (Universitets- og Bygningsstyrelsen, 2007). Dette bekræftes i internationale undersøgelser (Wright \& Cochrane, 2000; Bowen \& Rudenstine, 1992; Rodwell \& Neumann, 2007). Disse undersøgelser giver anledning til at overveje, om tørre fag har et større incitament til at fremme de studerendes studieforhold i form af bl.a. opkvalificering af vejlederkompetencer. Det kan derfor overvejes, om der er brug for at drøfte, om man fremover bør differentiere i brugen af vejlederbreve ved de forskellige hovedområder og på universitetets vejlederkurser. Central rammesætning via et institut eller via specifikke vejlederbreve for hovedområderne kunne være en mulighed i de fag, hvor udlevering af personligt vejlederbrev ikke nødvendigvis giver mening. Her kan identificeres andre veje til forventningsafstemning mellem studerende og vejleder. På den anden side kan processen i udarbejdelse af vejlederbrevet ses som en pædagogisk modning, uanset hvilket fakultet man kommer fra, og hvordan vejlederbrevet anvendes - givet at vejlederbrevet afspejler de ovennævnte kvaliteter. En hypotese kan være, at nytten af at udlevere vejlederbreve afhænger af, hvor tæt samarbejdet i hverdagen er mellem vejleder og studerende. Hvis forventningsafstemning er en naturlig og integreret del af det daglige samarbejde, kan det overflødiggøre udlevering af vejlederbrevet til den studerende. Vejlederbrevet kan i stedet ses som en bevidstgørelse af vejlederen om betydningen af forventningsafstemning. Dette er $\mathrm{fx}$ belyst i tabel 1 , hvor $1 / 3$ svarer, at de har deres vejlederbrev i tankerne under vejledning af studerende. Ovenstående hypotese har ikke kunnet identificeres i litteraturen, hvorfor den bør undersøges i fremtidige, kontrollerede studier.

I nærværende undersøgelse anvendes vejlederbrevet oftere til speciale- end ph.d.studerende (figur 2). En forklaring herpå kan være, at vejlederbrevet har en større berettigelse i kortere og mere intensive vejledningsforløb, hvor det er vigtigt hurtigt at afstemme forventninger og synliggøre sammenhænge mellem læringsmål og vurderingskrav, idet omfang og indhold af vejledning er rammesat anderledes end i et ph.d.-forløb. Vi formoder dog, at forskellen i anvendelse af vejlederbrevet mellem speciale- og ph.d.-studerende udlignes over tid, idet flere i undersøgelsen responderer, at de har tænkt sig at anvende vejlederbrevet i fremtiden og dermed også ved opstart af ph.d.-forløb. 
Det kan undre, at få anvender vejlederbrevet som en synliggørelse af vejledningspraksis på nettet. Dette kan bero på, at vejlederbrevet fortsat er nyt på universitetet. Måske ligger der også en indirekte afspejling af, hvordan undervisningskulturen er på universitetet; at den har et privat præg, og at der endnu ikke er tradition for at synliggøre refleksioner over egne undervisnings- og vejledningspraksisser. En anden forklaring kan være, at vejlederbrevene ikke har en kvalitet der gør, at vejlederne betragter dem som et betydningsfuldt dokument, hvorfor graden af synlighed på nettet er reduceret til et minimum.

Ovennævnte hypoteser kræver både en kvalitativ og en kvantitativ undersøgelsestilgang. Fx bør det udforskes, om der reelt er en forskel i vejledningsrelationen, og dermed hvor anvendelig vejlederbrevet er afhængig af, hvor tæt samarbejdet i hverdagen er mellem den studerende og vejleder. Indholdet og kvaliteten af vejlederbreve bør ligeledes undersøges i relation til, hvorfor vejlederbrevene anvendes eller ej, samt hvilken effekt dokumenterne måtte have på den studerendes læring. Sidstnævnte bør i sidste ende berettige vejlederbrevenes eksistens og anvendelse.

\section{Studiets styrker og svagheder}

Af styrker ved denne undersøgelse kan nævnes, at ca. 2/3 responderede på spørgeskemaet om brugen af vejlederbrev på trods af den korte responstid. Resultaterne kan dog være biased af, at de med størst interesse for vejlederbrevet har taget sig tid til at besvare spørgeskemaet - et selektionsproblem der kan have overestimeret brugen af vejlederbrevet. Stikprøvestørrelsen repræsenterer en tiendedel af VIP-ansatte på universitetet. Undersøgelsen kan derfor ikke ses som repræsentativ for samtlige undervisere på universitetet.

Som tidligere nævnt er undersøgelsen foretaget relativt kort tid efter afholdelsen af kurserne, hvilket kan forklare en begrænset implementering og brug af vejlederbrevene, da nogle vejledere måske ikke har fået nye studerende siden udarbejdelse af vejlederbrevet. På trods af ovenstående antager vi, at vores undersøgelse alligevel afspejler en tendens blandt de, der har været på vejlederkursus og er blevet introduceret til at anvende vejlederbrevet.

I undersøgelsen ses en trend mod, at deltagere fra Arts bruger vejlederbrevet hyppigere end andre hovedområder. Der skal dog tages forbehold for de få deltagere fra Arts. Ligeledes ses, at vejlederbrevet anvendes hyppigere til specialevejledning end til ph.d.-vejledning. Dette resultat kan være biased af den korte implementeringsperiode, hvor vejlederne ikke har nået at få nye ph.d.-studerende. Vi kender heller ikke det absolutte antal ph.d.- og specialestuderende, som respondenterne er vejledere for. Ej heller om der kan være variation mellem antal af kandidat- og ph.d.- 
studerende imellem fagområder samt, om alle undervisere har ph.d.-studerende. Sidstnævnte kan have påvirket vores estimat til at vise en falsk forskel.

Som allerede antydet har implementeringsperioden været forholdsvis kort, og kun få vejledere har nået at deltage i kurserne siden 2008, hvilket sammenlagt begrænser muligheden for at se målbare effekter på den aktuelle vejledningspraksis. Derfor ser det heller ikke ud til, at vejlederbrevet er så integreret en del af vejledningen, at det er naturligt at lægge det ud på hjemmesider.

\section{Konklusion}

Trods vejlederbrevets korte historie på AU ser det ud til, at vejlederbrevet har sin berettigelse - specielt i de tørre fag, hvor vejleder og studerende ikke har et tæt dagligt samarbejde. I våde fag, hvor der er et tæt samarbejde mellem vejleder og studerende, er vejlederbrevet muligvis mindre oplagt at anvende som et direkte redskab til forventningsafstemning. Uanset hvordan vejlederbrevet anvendes, giver selve processen med at formulere et vejlederbrev en forpligtende form og en klargørende effekt. At udarbejde et vejlederbrev kan derfor ses som en pædagogisk modning af vejlederen og dermed som en mulighed for at forbedre betingelserne for de studerendes læringsarbejde i forbindelse med skriftlige opgaver på universitetet. Kvaliteten af indholdet i vejlederbreve har dog afgørende betydning for, at vejlederbrevet kan betragtes som et godt pædagogisk værktøj i vejledningsprocessen, hvilket denne undersøgelse ikke har kunnet besvare.

\section{Taksigelser}

Vi takker kursussekretær Birthe Tillgaard for assistance med maillister og centerleder Torben K. Jensen for hjælp med udformning af spørgsmål til spørgeskemaet.

Sussie Laustsen er cand.cur., ph.d. og adjunkt ved Sektion for Sygeplejevidenskab, Institut for Folkesundhed og Institut for Klinisk Medicin på Aarhus Universitet. Underviser i metode, evidensbaseret viden og kliniske retningslinjer og har undervisnings- og vejledererfaring for såvel kliniske forskningsprojekter, som opgaver på BA-, kandidat- og ph.d.- niveau. Forskningsfeltet omhandler effekten af træning hos hjertesyge patienter på Aarhus Universitetshospital i Skejby.

Gitte Wichmann-Hansen er cand.mag. i Pædagogik, ph.d. i Uddannelsesforskning og lektor ved Center For Undervisningsudvikling og Digitale Medier på Aarhus Universitet. Gitte Wichmann-Hansen underviser og forsker $i$ vejledning - både vejledning knyttet til arbejdspladsoplaring og vejledning $i$ relation til opgave-, projekt- og forskningsforløb på universitetet.

\section{Hanne Aagaard er cand.cur., ph.d. i Sygepleje og adjunkt ved Institut for Folkesundhed på Aarhus Universitet og Børneafdelingen, Århus Universitetshospital. Hanne Aagaard underviser og forsker $i$ 'Complex Intervention' i relation til for tidligt fødte børn og deres familier. Som adjunkt knyttet til}


Sektion for Sygeplejevidenskab er en del af curriculum at yde vejledning til studerende på kandidat- og masterniveau.

Golnosh Bahrami er tandlæge med ph.d. i Odontologi og forskningsadjunkt ved Odontologisk Institut på Aarhus Universitet. Golnosh Bahrami har desuden klinisk undervisning på Odontologisk Institut og er ansat $i$ Region Syddanmark som tandlagekonsulent.

Pia Dreyer er sygeplejerske, cand.cur., ph.d. og adjunkt ved Sektion for Sygeplejevidenskab, Institut for Folkesundhed, Health på Aarhus Universitet. Pia Dreyer underviser og forsker indenfor det intensive område og hjemmerespiratorbehandling med det frnomenologisk hermeneutiske som inspirerende metodetilgang.

\section{Litteratur}

Biggs, J., \& Tang, C. (2007). Teaching for Quality Learning at University. Open University Press.

Bowen, G., \& Rudenstine, N. L. (1992). In Search of the PhD. Princeton: Princeton University Press.

Cullen, D. J., Pearson, M., Saha L. J., \& Spear, R. H. (1994). Establishing Effective PhD Supervision. Canberra: Australian Government Publishing Service.

Dysthe, O., Hertzberg, F., \& Hoel, T. L. (2000). Skrive for at lære. Århus: Forlaget Klim.

Green, H., \& Powell, S. (2005). Doctoral Study in Contemporary Higher Education. Maidenhead: SRHE and Open University Press.

Golde, C. M., \& Dore, T. M. (2001). At Cross Purposes: what the Experiences of Doctoral Students Reveal about Doctoral Education. Philadelphia, PA: Report prepared for the PCT. http://www.phd-survey.org

Handal, G., \& Lauvås, P. (2006). Forskningsveilederen. Oslo: Cappelen Akademisk Forlag.

Harboe, T. (2000). De studerendes forventninger til specialeskrivning - en spørgeskemaundersøgelse. Københavns Universitet, Det samfundsvidenskabelige Fakultet.

Hockey, J. (1996). "A contractual solution to problems in the supervision of $\mathrm{PhD}$ degrees in the UK" in Studies in Higher Education, 21 (3), 359-371.

Holdaway, E., Deblois, C., \& Winchester, I. (1995). "Supervision of graduate students", in The Canadian Journal of Higher Education, 25 (3), 1-29.

Ives, G., \& Rowley, G. (2005). "Supervisor selection or allocation and continuity of supervision: Ph.D students' progress and outcomes", in Studies in Higher Education, 30 (5), 535-55.

Kiley, M. (2003). “Conserver, Strategist or Transformer: The experiences of postgraduate student sojourners", in Teaching in Higher Education, 8 (3), 345-356.

Kiley, M., \& Mullins, G. (Eds.). (2008). Quality in postgraduate research: Research education in the new global environment. Canberra: CEDAM, ANU.

Moses, I. (1985). Supervising Postgraduates. Green Guide No. 3. Australia: Higher Education Research and Development Society of Australia, c/o University of South Wales. 
Rienecker, L., \& Stray Jørgensen, P. (2006). Den gode opgave. Håndbog i opgaveskrivning på de videregående uddannelser. 3. udg. Frederiksberg: Forlaget samfundslitteratur.

Rienecker, L., Harboe, T., \& Stray Jørgensen, P. (2005). Vejledning - en brugsbog for opgave - og specialevejledere på videregående uddannelser. Frederiksberg: Forlaget Samfundslitteratur.

Rodwell, J., \& Neumann, R. (2007). Predictors of Timely Doctoral Student Completions by Type of Attendance: The Utility Pragmatic Approach. Sydney, Australia: Macquarie Graduate School of Management.

Seagram, B. C., Gould, J., \& Pyke, S. W. (1998). “An investigation of gender and other variables on time to completion of doctoral degrees", in Research in Higher Education, 39 (3), 319-35.

Smeby, J-C. (2000). "Disciplinary differences in Norwegian graduate education", in Studies in Higher Education, 25 (1), 53-67.

Taylor, S., \& Beasley, N. (2005). A Handbook for Doctoral Supervisors. London: Routledge.

Universitets- og bygningsstyrelsen. (2007). Undersøgelse af årsager til frafald blandt ph.d.-studerende. København: Epinion Capacent.

Wichmann-Hansen, G., Eika, B., \& Mørcke, A. M. (2007). “Hvad findes der af litteratur om vejledning? -Litteratursøgning med fokus på publicerede, evidensbaserede studier", i Dansk Universitetspædagogisk Tidsskrift, 3, 11-19.

Woolhouse, M. (2002). "Supervising dissertation projects: expectations of supervisors and students", in Innovations in Education \& Teaching International, 39,137-44.

Wright, T. (2003). "Postgraduate research students: people in context?", in British Journal of Guidance \& Counselling, 31 (2), 209-227.

Wright, T., \& Cochrane, R. (2000). “Factors influencing successful submission of PhD theses", in Studies in Higher Education, 25 (2), 181-195. 